\title{
PENERAPAN PENDEKATAN SAINTIFIK MELALUI MODEL PROJECT BASED LEARNING UNTUK MENINGKATKAN KETRAMPILAN PROSES DAN HASIL BELAJAR SISWA KELAS IV SD NEGERI SEWORAN, WONOSEGORO
}

\author{
Umi Faizah \\ Irakalida12@tri.blackberry.com \\ SDN Seworan, Wonosegoro, Boyolali
}

\begin{abstract}
ABSTRAK
Tujuan penelitian ini adalah untuk meningkatkan ketrampilan proses dan hasil belajar melalui pendekatan saintifik pada sub tema macam-macam sumber energi dengan menggunakan model project based learning (PjBL) pada siswa kelas IV SDN Seworan. Jenis penelitian yang digunakan dalam penelitian ini adalah penelitian tindakan kelas yang terdiri dari dua siklus. Instrumen pengumpulan data menggunakan rubrik ketrampilan proses, dan soal tes untuk muatan Bahasa Indonesia dan IPA. Analisis data dilakukan dengan menggunakan analisis deskriftif komparatif yaitu membandingkan kondisi awal sebelum dilakukan tindakan, hasil siklus 1 , dan siklus 2. Hasil penelitian menunjukkan temuan: 1) model pembelajaran $P J B L$ dilakukan dengan langkah-langkah; a) penentuan pertanyaan mendasar, b) mendesain perencanaan proyek, c) Menyusun jadwal, d) Memonitor peserta didik dan kemajuan proyek, e) Menilai hasil proyek, f) Mengevaluasi pengalaman. Temuan lain adalah bahwa model pembelajaran $P B J L$ terbukti meningkatkan ketrampilan proses sub tema macam-macam sumber energi. Persentase peningkatan ketrampilan proses sub tema macam-macam sumber energi sebesar $26 \%$ pada siklus 1 dan 30,67\% untuk siklus 2 . b) meningkatkan persentase jumlah siswa yang mencapai ketuntasan belajar minimal(KKM) berikut : kondisi awal, persentase pencapaian kriteria ketuntasan minimal(KKM) untuk muatan Bahasa Indonesia sebesar 40\%(6 siswa), pada siklus 1 persentase meningkat menjadi 60\%(9 siswa) dan pada siklus 2 persentase jumlah siswa yang mencapai KKM meningkat menjadi $73,33 \%(11$ siswa). Sedangkan untuk muatan IPA kondisi awal persentase pencapaian kriteria ketuntasan minimal(KKM) sebesar 46,67\%,(7 siswa) pada siklus 1 persentase meningkat menjadi $60 \%$ (9 siswa) dan pada siklus 2 persentase jumlah siswa yang mencapai KKM meningkat menjadi 80\%(12 siswa).
\end{abstract}

Kata kunci: ketrampilan proses, hasil belajar, pendekatan saintifik, model pembelajaran PjBL.

\section{PENDAHULUAN}

Dalam mencapai tujuan pendidikan, pemerintah telah melakukan standarisasi dan profesionalisasi pendidikan seperti yang tertuang dalam Peraturan 
Pemerintah No. 19 Tahun 2005 tentang Standar Nasional Pendidikan (SNP), yang telah dirubah dalam Peraturan Pemerintah No. 32 Tahun 2013. Standar Nasional Pendidikan meliputi 8 Standar. Salah satu diantaranya adalah Standar Kelulusan yaitu kriteria mengenai kualifikasi kemampuan lulusan yang mencakup sikap, pengetahuan dan ketrampilan.

Pada kurikulum sebelumnya terdapat beberapa kelemahan, salah satu diantaranya kempotensi yang dikembangkan lebih didominasi aspek pengetahuan, belum sepenuhnya menggambarkan secara holistik dari aspek sikap, pengetahuan dan ketrampilan. Di samping itu, berbagai ketrampilan sesuai dengan perkembangan masyarakat, seperti pendidikan karakter, metodologi pembelajaran aktif, keseimbangan antara soft skill dan hard skill belum terakomodasi dalam kurikulum. Kurikulum 2013 disusun salah satunya berdasarkann kelemahan diatas. Dengan demikian, dalam mencapai standar kompetensi lulusan, kurikulum 2013 meliputi pendidikan karakter, metodologi pembelajaran aktif, dan keseimbangan antara soft skill dan hard skill mencakup 3 aspek pengetahuan, sikap dan ketrampilan secara terpadu.

Kurikulum 2013 untuk SD/MI menggunakan pendekatan tematik integratif dari kelas 1 sampai kelas 6 dan mengamanatkan pendekatan saintifik. Hal tersebut didasarkan pada kecenderungan belajar usia sekolah dasar yang memiliki tiga ciri konkrit, hirarki dan integras dengan proses pembelajaran mengamati, menanya, mengumpulkan informasi, mengasosiasi dan mengkomunikasikan. Oleh karena itu, proses pembelajaran dalam kurikulum 2013 harus menampakkan proses pembelajaran yang memungkinkan siswa berlatih mengembangkan ketrampilan saintifik, yang akan berdampak pada meningkatnya hasil belajar. Namun dalam kenyataannya pembelajaran di SDN Seworan masih bersifat konvensional dan tidak menyentuh ranah dimensi itu sendiri. Pembelajaran yang bersifat konvensional tidak memberikan kesempatan pada siswa untuk mengemabgkan potensi siswaitu sendiri. Pada pembelajaran yang bersifat konvensional cenderung bersifat teacher centered, guru menjelaskan sedangkan siswa lebih banyak mendengarkan dan siswa juga dituntut menghafal konsep itu sendiri. Hal itu berakibat pada rendahnya ketrampilan proses dan hasil belajar siswa di SDN Seworan.

Kemampuan siswa dalam ketrampilan proses siswa terutama dalam mengamati, menanya, mencoba, mengolah, menyaji, menalar, mencipta, menyajikan dan mengkomunikasikan masih sangat rendah yaitu 9 siswa ( 60\% ) pada katagori rendah dan $6 \operatorname{siswa(~} 40 \%$ )pada kondisi sedang. Selain itu berdasarkan hasil studi dokumen daftar nilai siswa dari hasil belajar persentase ketuntasan belajar yang mencapai di atas KKM juga masih sangat rendah yaitu 
40\% untuk muatan IPA dan bahasa Indonesia 46,67\% untuk muatan Bahasa Indonesia.

Untuk meningkatkan hasil belajar salah satunya adalah menyelaraskan kegiatan pembelajaran dengan nuansa Kurikulum 2013 yang menekankan pada dimensi pedagogik modern dalam pembelajaran yaitu dengan menggunakan pendekatan ilmiah (scientific approach). Pendekatan Saintifik meliputi kegiatan mengamati, menanya, mengumpulkan infirmasi, mengasosiasi, menalar, mengolah informasi, menyajikan serta mengkomunikasikan. Sehingga dalam kurikulun 2013 ini siswa terlibat secara aktif dalam pembelajaran. Agar siswa terlibat aktif dalam pembelajaran dibutuhkan model pembelajaran yang sesuai dengan karakter siswa dengan pendekatan saintifik. Salah satu model pembelajaran yang dapat diterapakan sebagai strategi pemecahan masalah adalah model pambelajaran project based learning. Dipandang dari kualitas hasil yang akan diperoleh siswa, maka project based learning akan memiliki kontribusi yang lebih baik daripada model konvensional yang hanya menerapkan satu arah saja. Dalam pembelajaran project based learning pembelajaran mendorong kemampuan peserta didik untuk menghasilkan karya kontekstual baik individual maupun kelompok.

Berdasarkan latar belakang seperti tersebut di atas, permasalahan penelitian yang akan dipecahkan dalam PTK ini adalah apakah model pembelajaran PJBL dapat meningkatkan ketrampilan proses saintifik dan hasil belajar siswa sub tema macam-macam sumber energi.

\section{KAJIAN PUSTAKA}

\section{Pembelajaran Tematik Integratif}

Pembelajaran tematik integreted merupakan salah satu pendekatan dalam mengintegrasikan kurikulum. Pendekatan ini diusulkan oleh Fogarty (2009) pertama kali tahun 1991. Fogarty (2009) mengusulkan 10 pendekatan dalam mengintegrasikan kurikulum, sehingga menghasilkan 10 model. Pada bagian ini akan dipaparkan model kurikulum 2013,yakni model webbed. Kurikulum webbed merepresentasiakan pendekatan tematik untuk mengintegrasikan kurikulum. Pendekatan tematik dimulai dengan menentukkan suatu tema yang dikembangkan. Tema adalah sebuah gagasan besar yang menjadi pusat dari pengembangan kurikulum dan memacu siswa untuk belajar. Tema dapat dianalogikan dengan sebuah payung yang darinya menyebar berbagai mata pelajaran. Pengitegrasian tersebut dilakukan dalam dua hal, yaitu integrasi sikap, ketrampilan dan pengetahuan dalam proses pembelajaran dan integrasi berbagai konsep dasar yang berkaitan. Jadi dalam pembelajaran tematik integratif ini guru melakukan pertimbangan-pertimbangan dengan melihat kompetensi dasar dari berbagai mata 
pelajaran agar tercipta kesinambungan dari kompetensi-kompetensi tersebut ke dalam satu tema (http:www.m-edukasi.web.id).

Berdasarkan uraian di atas pembelajaran tematik merupakan model pembelajaran yang mengintegrasikan kompetensi dasar dari berbagai mata pelajaran agar tercipta kesinambungan dari kompetensi-kompetensi tersebut ke dalam satu tema.

Pembelajaran tematik terpadu diajarkan berdasarkan tahapan tertentu. Menurut Pelatihan Implementasi Kurikulum 2013(kemendikbud, 2014) disebutkan ada beberapa tahapan dalam pembelajaran tematik terpadu yaitu pertama guru harus mengacu pada tema sebagai pemersatu berbagai muatan pelajaran untuk satu tahun. Kedua guru melakukan analisis Standar Kompetensi Lulusan, kompetensi inti, kompetensi Dasar dan membuat indikator dengan tetap memperhatikan muatan pelajaran. Cakupan KD pada sub tema Macam-Macam Sumber Energi adalah:

1) Cakupan KD pada muatan Bahasa Indonesia

3.1 Menggali informasi dari teks laporan hasil pengamatan tentang gaya ,gerak, energi panas, bunyi dan cahaya dengan bantuan guru dan teman dalam bahasa indonesia lisan dan tulis dengan memilih dan memilah kosa kata baku.

3.2 menguraikan teks intruksi tentang pemeliharaan panca indera serta penggunaan alat teknologi modern dan tradisional dengan bantuan guru dan teman dalam bahasa lisan dan tulis dengan memilih dan memilah kosa kata baku.

4.1 Mengamati, mengolah, dan menyajikan teks laporan hasil pengamatan tentang gaya, gerak, dan energi panas, bunyi dan cahaya dalam Bahasa Indonesia lisan dan tulis dengan memilih dan memilah kosakata baku.

4.2 Menerangkan dan mempraktikkan teks arahan atau petunjuk tentang pemeliharaan panca indera serta penggunaan teknologi modern dalam Bahasa Indonesia lisan dan tulis dengan memilih dan memilah kosakata baku.

2) Cakupan KD pada muatan IPA

3.4 Membedakan berbagai bentuk energi melalui pengamatan dan mendiskripsikan pemanfaatanya dalam kehidupan sehari-hari.

4.7 Menyajikan laporan hasil pengamatan teknologi yang digunakan di kehidupan sehari-hari serta kemudahan yang diperoleh oleh masyarakat dengan memanfaatkan teknologi tersebut.

Berdasarkan hakikat dan tahapan pembelajaran tematik seperti telah diuraikan di atas, maka para guru perlu mempertimbangkan rancangan 
ketrampilan proses, memberikan pengalaman autentik pada siswa, menggunakan model yang dapat meningkatkan ketrampilan proses dan hasil belajar melalui pendekatan saintifik misalnya $\mathrm{Pj}$ dan merancang penilaian yang dapat mengukur proses keterangan secara autentik misal penilaian autentik. Uraian secara mendalam atau mendetail tentang pendeatan saintifik,ketrampilan proses, $P j B L$ dan penilaian autentik sendiri.

\section{Hakikat Pendekatan Saintifik}

Hosnan (2014:34) mengemukakan bahwa Implementasi kurikulum 2013 dalam pembelajaran dengan pendekatan saintifik adalah proses pembelajaran yang dirancang sedemikian rupa agar peserta didik secara aktif mengonstruk konsep, hukum atau prinsip melalui tahapan-tahapan mengamati, merumuskan masalah, mengajukan atau merumuskan hipotesis, mengumpulkan data dengan berbagai tehnik, menganalisis data, menarik kesimpulan dan mengkomunikasikan konsep, hukum atau prinsip yang "ditemukan".

Kondisi pembelajaran yang diharapkan dari pendekatan saintik adalah mendorong peserta didik dalam mencari tahu dari berbagai sumber melalui observasi, bukan hanya diberi tahu. Pemilihan pendekatan saintifik sejalan dengan ketrampilan proses pembelajaran yang digunakan untuk mengukur tingkat kemampuan siswa dalam mengamati, merumuskan masalah, mengajukan hipotesis, mengumpulkan data, menganalisis data, menarik kesimpulan, dan mengkomunikasikan.

Berdasarkan uraian hakikat pendekatan saintifik seperti diuraikan diatas maka para guru perlu mempertimbangakan rancangan ketrampilan proses yang sejalan dengan pendekatan saintifik untuk meningkatkankan hasil belajar dan ketrampilan proses siswa. Uraian ketrampilan proses yang sejalan pada pendekatan saintifik akan dibahas pada bagian selanjutnya.

\section{Ketrampilan Proses}

Ketrampilan proses merupakan bagian bagian dari domin kognitif dalam pembelajaran. Menurut Wahyudi dan Kriswadani (2010: 53) ketrampilan proses merupakan kegiatan belajar mengajar yang berfokus pada penelitian siswa secara aktif dan kreatif dalam memperoleh hasil belajar. Hasil belajar yg diperoleh siswa tidak terbatas pada aspek pengetahuan saja melainkan bagaimana proses mencapai tujuan pembelajaran yang diharapkan dapat terpenuhi.

Menurut Rustaman (2005:79) menyebutkan indikator ketrampilan proses IPA meliputi 1) Mengamati, yaitu proses pengumpulan data tentang fenomena atau peristiwa menggunakan inderanya. 2) mengelompokkan merupakan suatu sistematika yang digunakan untuk menggolongkan syarat-syarat tertentu. 3) 
Menafsirkan pengamatan merupakan menarik kesimpulan tentatif dari di catatnya. 4) Meramalkan ( prediksi) merupakan memperkirakan berdasarkan pada hasil pengamatan yang riabel. 5) Mengajukan pertanyaan dapat diperoleh siswa dengan mengajukan pertanyaan apa, mengapa, bagaimana, pertanyaan untuk meminta penjelasan atau pertanyaan yang berlatar belakang hipotesis. 6) Merumuskan hipotesis, hipotesis merupakan suatu dugaan yang dapat diuji mengenai bagaimana dan mengapa sesuatu terjadi. 7) Merencanakan suatu percobaan, ketrampilan merencanakan percobaan dapat dimiliki siswa, jika siswa tersebut dapat mentukan alat dan bahan yang akan digunakan dalam percobaan, selanjutnya siswa perlu menentukkan apa yang akan diamati, atau ditulis, menentukkan cara dan langkah kerja. 8) Menerapkan konsep pada pengalaman baru untuk menjelaskan apa yang terjadi. 9) Berkomunikasi meliputi ketrampilan membaca grafik, tabel, atau diagram hasil percobaan.

Ketrampilan proses Bahasa Indonesia meliputi 1) mengamati, 2) menggolongkan, 3) menafsirkan, 4) menerapkan, 5) mengkomunikasikan. Berdasar-kan ketrampilan pada muatan IPA dan Bahasa Indonesia diatas, peneliti mengambil ketrampilan proses yang sesuai dengan materi sub tema macammacam sumber energi yaitu mengamati,merumuskan masalah, mengajukan hipotesis, mengumpulkan data, menganalisis data, menarik kesimpulan, dan mengkomuni-kasikan.

Berdasarkan uraian di atas terlihat bahwa pada prinsipnya ketrampilan proses dengan pendekatan saintifik memberikan kesempatan kepada setiap siswa untuk menemukkan dan mengkonstruksi sendiri pemahaman ide dan konsep pembelajar-an tematik. Tantangan bagi guru SD dalam pembelajaran tematik adalah seberapa tinggi siswa mampu menguasai aspek pengetahuan, sikap dan ketrampilan dan konsisten dalam memilih model pembelajaran yang tepat. Apabila tantangan ini dijawab dengan tepat, maka dimensi-dimensi pembelajaran tematik, yaitu ketrampilan proses pembelajaran tematik dan hasil belajar siswa melalui pendekatan saintifik dapat ditingkatkan .

\section{Model Pembelajaran Project Based Learning (PjBL)}

Pembelajaran model PjBL menurut Joel L. Klient merupakan strategi pembelajaran yang memberdayakan siswa untuk memperolah pengetahuan dan pemahaman baru berdasarkan pengalamannya melalui berbagai presentasi.

Menurut Cord et al, sebagaimana yang dikutip Rais (2010:4) merupakan sebuah model pembelajaran yang inovatif yang menekankan pembelajaran kontekstual melalui kegiatan-kegiatan yang kompleks seperti memberi kebebasan peserta didik untuk bereksplorasi merencanakan aktivitas belajar, melaksanaknan proyek secara kolaboratif, dan pada akhirnya 
menghasilkan suatu produk. PjBL membantu peserta didik mengembangkan berbagai kemampuan seperti intelektual, sosial,emosional, dan moral (Bas,G.,2010:11)

Berdasarkan pendapat diatas maka dapat disimpulkan pembelajaran berbasis proyek merupakan model pembelajaran yang memberikan yang memberi kesempatan kepada guru untuk mengelola pembelajaran di kelas dengan melibatkan di proyek. Kerja proyek memuat tugas-tugas kompleks berdasarkan permasalahan (problem) sebagai langkah awal dalam mengumpulkan dan mengintegrasikan pengetahuan baru berdasarkan pengalamannya dalam beraktivitas secara nyata dan menuntut siswa utuk melakukan kegiatan merancang, memecahkan masalah, membuat keputusan, melakukan kegiatan investigasi, serta memberikan kesempatan siswa untuk bekerja mandiri maupun kelompok. Hasil akhir dari kerja proyek tersebut adalah suatu produk yang antara lain berupa laporan tertulis atau lisan, presentasi atau rekomendasi. Lebih lanjut menurut The George Lucas Educational Foundation (2005) menjelaskan bahwa langkah-langkah atau sintak model $P j B L$ meliputi penentuan pertanyaan mendasar, mendesain perencanaan proyek, menyusun jadwal, memonitor peserta didik dan kemajuan proyek, menilai hasil proyek, dan mengevaluasi pengalaman.

PjBL merupakan pembelajaran merupakan kerja proyek berdasarkan suatu permasalahan dengan mengintegrasikan dan mengumpulkan pengetahuan baru berdasarkan pengalamannya. Berkaitan dengan hakikat dan langkah PJBL ini, menurut materi pelatihan kurikulum 2013 yang diterbitkan oleh BPSDMPK dan PMP tahun 2013 dan Center for Youth Development and education- Boston (Muliawati, 2010:10) adalah meningkatkan motivasi belajar peserta didik untuk belajar dan mendorong kemampuan mereka untuk melakukan pekerjaaan penting, Meningkatkan kemampuan pemecahan masalah, membuat peserta didik menjadi lebih baik aktif dan memecahkan problem-problem yang kompleks, meningkatkan kolaborasi, mendorong peserta didik untuk mengembangkan dan mempraktikkan ketrampilan berkomunikasi, meningkatkan ketrampilan peserta didik dalam mengelola sumber, dan menyediakan pengalaman belajar yang melibatkan peserta didik secara kompleks dan dirancang untuk berkembang sesuai dunia nyata. Namun demikian, PjBL juga memiliki kelemahan yaitu memerlukan banyak waktu untuk penyelesaian masalah dan membutuhkan biaya yang cukup banyak.

Berdasarkan hakikat pembelajaran tematik, karakteristik pembelajaran tematik seperti telah diuraikan di atas, maka model PJBL dapat disajikan salah satu alternatif model pembelajaran tematik di SD. Implementasi model PJBL, secara teoritik dapat meningkatkan kompetensi ketrampilan proses tematik para siswa yang nantinya akan berdampak pada penguasaan konsep-konsep tematik. Berbagai penelitian tindakan membuktikan potensi PjBL secara empirik. Theresia 
Widyantini (2014), meneliti tentang penerapan model Project Based Learning dalam materi Pola Bilangan Kelas VII menyatakan bahwa siswa mampu mengasilakn proyek suatu produk yang antara lain berupa laporan tertulis, presentasi dan rekomendasi. Almes Gangga (2013) yang berjudul Penerapan Model Pembelajaran Project Based Learning dalam meningkatkan motivasi dan hasil belajar bahwa. Model Pembelajaran Project Based Learning dapat meningkatkan secara signifikan hasil belajar aspek kognitif, afektif dan psikomotorik siswa pada standar kompetensi perbaikan ringan rangkaian listrik dan instrumen.

Uraian tentang hakikat PjBL dan temuan berbagai penelitian di atas berimplikasi pada desain pembelajaran dan penilaian pembelajaran. Penilaian tidak cukup dengan tes melainkan melalui penilaian autentik yang mencakup ranah sikap, ketrampilan, dan pengetahuan. Uraian tentang penilaian autentik pembelajaran tematik akan dibahas pada bagian selanjutnya. Tujuan dari model Project Based Learning (PjBL) untuk membantu siswa memperoleh pengalaman dan mengubah ketrampilan, nilai atau norma sebagai pengendali sikap dan perilaku siswa.

Mencermati uraian tentang sintak $P j B L$ seperti di atas, sebenarnya $P j B L$ dapat digunakan sebagai sarana pendekatan saintifik. Langkah penentuan pertanyaan mendasar dilakukan dengan memunculkan pertanyaan seputar proyek sejalan dengan aktivitas mengumpulkan informasin mengumpulkan data. Langkah mendesain pelaksanaan proyek sejalan dengan aktivitas . mengajukan hipotesis, mengumpulkan data dan menganalisis data, 3) Langkah menyusun jadwal, memonitor peserta didik dan kemajuan proyek relevan dengan mengumpulkan informasi dan mengasosiasi. Menilai hasil dan mengevaluasi pengalaman sejalan dengan mengkomunikasikan.

Kesepadanan sintak PjBL dengan ketrampilan proses ilmiah dalam pendekatan saintifik nampaknya juga relevan dengan ketrampilan proses dalam pembelajaran sub tema macam-macam sumber energi. Kegiatan mengamati dalam ketrampilan proses sejalan dengan proses mengamati dalam pendekatan sintifik dan kegiatan mendesain pelaksanaan proyek dalam sintak PjBL. Kegiatan mendesain pelaksanaan proyek dalam sintak PjBL merupakan kegiatan yang relevan dengan kegiatan merumuskan masalah, mengajukan hipotesis, mengumpulkan data. Kegiatan menyusun jadwal, memonitor peserta didik dan kemajuan proyek dalam langkah $P j B L$ relevan dengan kegiatan menganalisis data. Aktivitas menilai hasil dan mengevaluasi pengalaman sejalan dengan kegiatan mengkomunikasikan dalam ketrampilan proses. 
Dalam penelitian PTK ini enam pembelajaran didesain berdasarkan sintak PjBL dan komponen-komponen ketrampilan proses pembelajaran dengan pendekatan saintifik menjadi obyek dalam pembelajaran.

\section{Penilian Autentik}

Menurut Nurhadi ( 2004:72) penilitian autentik merupakan proses pengumpulan informasi oleh guru tentang perkembangan dan pencapain pembelajaran yang dilakukan oleh peserta didik melalui berbagai teknik yang mampu mengungkapkan dan membuktikan atau menunjukkan secara tepat bahwa tujuan pembelajaran telah benar-benar dikuasai atau dicapai.

Menurut Abdul Majid (2006:186) penilaian autentik merupakan proses pengumpulan informasi oleh guru tentang perkembangan dan pencapaian pembelajaran yang dilakukan siswa melalui teknik yang mampu mengungkapkan, membuktikan dan menunjukkan secara tepat bahwa tujuan pembelajaran dan kompetensi telah benar-benar dikuasai

Penilaian autentik mencoba menggabungkan kegiatan guru mengajar, kegiatan siswa belajar, motivasi dan keterlibatan peserta didik, serta keterampilan belajar. Karena penilaian itu merupakan bagian dari proses pembelajaran, guru dan peserta didik berbagi pemahaman tentang kriteria kinerja. Dalam beberapa kasus, peserta didik bahkan berkontribusi untuk mendefinisikan harapan atas tugas-tugas yang harus mereka lakukan.

Penilaian autentik sering digambarkan sebagai penilaian atas perkembangan peserta didik karena berfokus pada kemampuan mereka berkembang untuk belajar bagaimana belajar tentang subjek. Penilaian autentik harus mampu menggambarkan sikap, keterampilan, dan pengetahuan apa yang sudah atau belum dimiliki oleh peserta didik, bagaimana mereka menerapkan pengetahuannya, dalam hal apa mereka sudah atau belum mampu menerapkan perolehan belajar, dan sebagainya. Atas dasar itu, guru dapat mengidentifikasi materi apa yang sudah layak dilanjutkan dan untuk materi apa pula kegiatan remedial harus dilakukan.

Penilaian autentik terdiri dari berbagai teknik penilaian. Pertama, pengukuran langsung keterampilan peserta didik yang berhubungan dengan hasil jangka panjang pendidikan seperti kesuksesan di tempat kerja. Kedua, penilaian atas tugas-tugas yang memerlukan keterlibatan yang luas dan kinerja yang kompleks. Ketiga, analisis proses yang digunakan untuk menghasilkan respon peserta didik atas perolehan sikap, keterampilan, dan pengetahuan yang ada.

Jenis-jenis penilaian autentik menurut hosnan (2014: 396) terdiri dari : Penilaian sikap, penilaian dan pengetahuan, dan penilaian ketrampilan. Sedangkan dalam penelitian ini peneliti akan memfokuskan pada penilaian pengetahuan dan pengetahuan ketrampilan. 
Simpulan ini senada dengan ketentuan dalam lampiran Permendiknas No 81 a Tahun 2013, yang menyatakan bahwa penilaian autentik merupakan penilaian autentik merupakan penilaian dan pembelajaran secara terpadu. Penilaian autentik harus mencerminkan dunia nyata, bukan dunia sekolah. Menggunakan berbagai cara dan kriteria holistik (kompetensi utuh merefleksikan pengetahuan, ketrampilan dan sikap).

Berpijak pada permasalahan kesenjangan proses dan hasil belajar dan potensi $P j B L$ serta ketrampilan proses pembelajaran tematik seperti yang diuraikan di atas, maka kerangka pikir akan dibahas pada bagian selanjutnya.

\section{Kerangka Pikir}

Ketrampilan proses siswa kelas IV SDN Seworan tergolong masih rendah hal ini berdamapak pada hasil belajar siswa rendah pada semua Muatan. Hal ini disebabkan karena guru menyampaikan pembelajaran dengan cara konvensional dan tidak menyentuh ranah dimensi siswa itu sendiri. Sehingga kurang mampu merangsang motivasi siswa dalam mengikuti pembelajaran.

Salah satu cara yang dapat dilakukan guru untuk meningkatkan ketrmapilan proses dan hasil belajar adalah menggunakan model pembelajarn yang inovatif. Oleh karena itu dalam pembelajaran tematik dibutuhkan model yang mampu mengaktifkan siswanya, salah satunya model pembelajaran project based learning.

Dengan menggunakan model pembelajaran ini diharapkan proses pembelajaran lebih efektif dan efisien. Sehingga tercipta suasana interaktif antara guru dengan siswa dan siswa dengan siswa. Sehingga pembelajaran akan lebih bermakna bagi siswa dan diharapkan mampu meningkatkan ketrampilan proses dan hasil belajar siswa.

\section{METODE PENELITIAN}

Penelitian tindakan kelas (PTK) ini dilakukan di SD Seworan, Kecamatan Wonosegoro, Kabupaten Boyolali pada Sub Tema Macam-Macam Sumber Energi kelas IV semester 1 Tahun Pelajaran 2014/2015. Penelitian ini dilakukan dalam dua siklus. Siklus 1 dilaksanakan pada September minggu kedua dan siklus 2 dilaksanakan pada minggu ketiga bulan September. Dengan jumlah siswa lakilaki 9 dan perempuan 6. Sumber data primer berasal dari hasil pengukuran varibel penelitian tindakan kelas berikut:1) skor hasil belajar siswa 2) skor tingkat ketrampilan proses siwa pada pembelajaran tematik. Teknik pengumpulan data dalam penelitian ini adalah teknik tes dan teknik non tes. Teknik tes untuk mengukur hasil belajar dan teknik non tes untuk mengukur ketrampilan proses 
menggunakan rubrik ketrampilan proses. Validitas data menggunakan triangulasi sumber dan triangulasi metode.

Analisis data yang digunakan adalah teknik analisis deskriftif komparatif yaitu membandingkan hasil tes antar siklus. Data kuantitatif yang diperoleh di deskripsikan dalam bentuk kata-kata atau penjelasan. Baik data yang diperoleh dari hasil tes siswa. Rubik keterampilan proses siswa. Selanjutkan dilakukan komparasi data setiap siklus untuk memastikan ada tidaknya peningkatan hasil belajar siswa, peningkatan keterampilan proses. Sebagai tolak ukur keberhasilan pelaksanaan penelitian tindakan kelas ini ditetapkan indikator kinerja sebagai berikut: 1) Persentase jumlah siswa yang mencapai KKM sebesar $50 \%$ untuk siklus 1 , dan siklus 2 sebesar $70 \%$;2) meningkatnya keterampilan proses sains minimal sebesar $15 \%$ persen pada siklus 1 dan siklus 2 .

Prosedur PTK ini terdiri dari empat tahapan yang saling terkait dan berkesinambungan, yaitu perencanaan (planning), tindakan (action), observasi (observe), serta refleksi (reflect) (Arikunto, Suhardjono,\& Supardi, 2008:16).

\section{HASIL DAN PEMBAHASAN}

Setelah melakukan analisa terhadap data yang diperoleh dari dua siklus yang dilaksanakan, maka dapat disimpulkan bahwa penggunaan model pembelajaran Project Based Learning (PJBL) pada Sub Tema Macam- Macam Sumber Energi menunjukkan peningkatan Keterampilan proses dan ketuntasan hasil belajar siswa. Tabel 1 merangkum komparasi tingkat Keterampilan Proses dari kondisi awal, siklus 1, dan siklus 2:

Tabel 1.1 Komparasi Keterampilan Proses

\begin{tabular}{|l|c|c|}
\hline \multirow{2}{*}{ Pembelajaran } & \multicolumn{2}{|c|}{ Tingkat Keterampilan Proses } \\
\cline { 2 - 3 } & Mean & \% Kenaikan \\
\hline KondisiAwal & 22,40 & - \\
\hline Siklus 1 & 26 & 16,07 \\
\hline Siklus 2 & 30,67 & 17,96 \\
\hline
\end{tabular}

Dari data dalam Tabel 1.1 diatas, diperoleh temuan: a) pada kondisi awal, rata-rata tingkat keterampilan proses siswa baru mencapai 22,40 (skor maksimal ideal 40); b) pada siklus 1, rata-rata tingkat keterampilan proses siswa mencapai 26. 
Tabel 1.2 Komparasi Hasil Belajar Antar Siklus

\begin{tabular}{|c|c|c|c|c|c|c|c|c|c|c|c|c|}
\hline \multirow[b]{2}{*}{ Kategori } & \multicolumn{3}{|c|}{$\begin{array}{c}\text { Muatan Bahasa } \\
\text { Indonesia }\end{array}$} & \multicolumn{3}{|c|}{ \% kenaikan } & \multicolumn{3}{|c|}{ Muatan IPA } & \multicolumn{3}{|c|}{ \% kenaikan } \\
\hline & $\begin{array}{l}\Theta \\
\Xi \\
=\end{array}$ & $\begin{array}{l}\underset{=}{\Theta} \\
\frac{\infty}{\vec{n}}\end{array}$ & 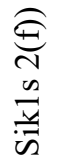 & $\stackrel{\pi}{2}$ & $\frac{-}{\frac{\pi}{\pi}}$ & $\begin{array}{l}\sim \\
\frac{a}{4} \\
\frac{a}{n}\end{array}$ & 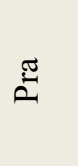 & $\frac{\vec{n}}{\vec{n}}$ & $\frac{N}{n}$ & 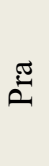 & $\vec{a}$ & $\frac{N}{\sqrt{u}}$ \\
\hline $\begin{array}{l}\text { Tinggi } \\
(\geq 67,5)\end{array}$ & 6 & 9 & 11 & - & 3 & 2 & 7 & 9 & 12 & - & 2 & 3 \\
\hline $\begin{array}{c}\text { Sedang } \\
(50-67,50)\end{array}$ & 5 & 4 & 4 & - & -1 & - & 2 & 5 & 3 & - & 3 & -2 \\
\hline $\begin{array}{c}\text { Rendah } \\
(67,5)\end{array}$ & 4 & 2 & - & - & -2 & -2 & 6 & 1 & - & - & -5 & -1 \\
\hline Rerata & 58 & 64,67 & 75,33 & - & 20 & 13,33 & 59,33 & 65,33 & 76 & - & 13,33 & 15 \\
\hline Max & 80 & 80 & 100 & - & - & 20 & 80 & 80 & 90 & - & - & 10 \\
\hline Min & 40 & 40 & 50 & - & - & 10 & 40 & 40 & 50 & - & - & 10 \\
\hline
\end{tabular}

Capaian ini menunjukkan peningkatan keterampilan sebesar $16,07 \%$; c) pada siklus 2, rata-rata keterampilan proses mencapai 30,67. Data ini menunjukkan peningkatan keterampilan proses sebesar 17,96\%. Komparasi tingkat pencapaian hasil belajar pada sub tema Macam-Macam Sumber Energi muatan Bahasa Indonesia dan IPA dapaat dijelaskan pada tabel 1.2.

Dari tabel 1.2 di atas diperoleh data sebagai berikut: a) pada kondisi awal, rerata hasil belajar untuk muatan Bahasa Indonesia mencapai 58, sedangkan persentase siswa yang mencapai KKM 40\% ( 6 siswa), untuk rerata hasil belajar muatan IPA mencapai 59,33, sedangkan persentase siswa yang mencapai KKM 46,67\% (7 siswa), b) pada siklus 1, rerata hasil belajar untuk muatan Bahasa Indonesia menjadi 64,67, sedangkan persentase siswa yang mencapai KKM 60\%( 9 Siswa) atau mengalami peningkatan 20\% (3 siswa), untuk rerata hasil belajar muatan IPA mencapai 65,33 , sedangkan persentase siswa yang mencapai KKM $60 \%$ (9 siswa) atau mengalami peningkatan 13,33\% (2 siswa), c) pada siklus 2 , rerata hasil belajar untuk muatan Bahasa Indonesia mencapai 75,33, sedangakan persentase siswa yang mencapai KKM 73,33\% (11 siswa) atau mengalami peningkatan $13,33 \%$ ( 2 siswa), untuk rerata hasil belajar muatan IPA mencapai 76, sedangkan persentase siswa yang mencapai KKM 75\% (12 siswa) atau mengalami peningkatan 15\% ( 3 siswa).

\section{Keberhasilan Model PjBL dalam Meningkatkan Ketrampilan Proses}


Pada tabel 1.1 komparasi ketrampilan proses kondisi awal, siklus 1, siklua 2 menunjukkan rerata ketrampilan proses pada kondisi awal 22,40, pada siklus 1 26 dan siklus 2 30,67. Temuan ini mengindikasi adanya peningkatan pada ketrampilan proses. Besaran peningkatan 16,07\% untuk siklus 1 dan 17,96\% untuk siklus 2. Jika dibandingkan dibandingkan dengan indikator kinerja 15 \%maka temuan tersebut telah mencapai keberhasilan.

Ini bermakna bahwa siswa mampu mengamati, merumuskan masalah, mengajukan hipotesis, mengumpulkan data, menganalisis data, menarik kesimpulan, dan mengkomunikasikan. Hasil temuan ini sejalan dengan penelitan Theresia Widyantini(2014) dan Almes Gangga(2013).

\section{Keberhasilan Model PJBL dalam Meningkatkan Hasil Belajar Siswa}

Pada tabel 1.2 komparasi hasil belajar siklus 1 dan siklus 2 menunjukkan temuan kondisi awal pada muatan Bahasa Indonesia rerata 58 pada siklus 1 rerata hasil belajar mencapai 64,67, sedangkan pada siklus 2 mencapai 75,33. Temuan ini mengindikasi adanya peningkatan hasil belajar siswa pada muatan Bahasa Indonesia. Besaran peningkatan 20\% untuk siklus 1 dan 13,33\% untuk siklus 2 . Ketuntasan hasil belajar siswa pada siklus 2 mencapai 73,33\%.

Pada muatan IPA kondisi awal, rerata 59,33, pada siklus 1 rerata 65,33, sedangkan pada siklus 2 rerata mencapai 76 . Dengan persentase peningkatan hasil belajar $20 \%$ pada siklus 1 dan $15 \%$ pada siklus 2 dengan ketuntasan hasil belajar siswa pada siklus 2 mencapai 75\%. Jika dibandingkan dengan indikator kinerja sebesar 70\%, maka PTK ini dikatakan berhasil karena melampui 70\%.

Keampuhan model PjBL mampu meningkatkan ketrampilan proses dan hasil belajar siswa. Keampuhan ini terbukti dalam sintak pembelajaran;1) sintak pertama penentuan pertanyaan mendasar terbukti siswa mampu merumuskan masalah dan mengumpulkan data, 2) sintak kedua mendesain pelaksanaan proyek terbukti siswa mampu mengajukan hipotesis, mengumpulkan data dan menganalisis data, 3) sintak menyusun jadwal dan memonitor peserta didik dan kemajuan proyek terbukti siswa mampu mengumpulkan informasi dan menarik kesimpulan, 4) sintak menilai hasil dan mengevaluaasi pengalaman terbukti siswa mampu mengkomunikasikan hasil proyek. Hasil temuan ini sejalan dengan penelitan Theresia Widyantini (2014) dan Almes Gangga.

\section{SIMPULAN DAN SARAN}

Berdasarkan hasil penelitian dan pembahasan, dapat disimpulkan bahwa Model Pembelajaran PjBL dapat:

1. Meningkatkan keterampilan proses pembelajaran tematik kelas IV SD Negeri Seworan, Kecamatan Wonosegoro, Kabupaten Boyolali, sebesar 26\% pada 
siklus 1 dan $30,67 \%$ pada siklus 2 .

2. Meningkatkan hasil belajar siswa kelas IV SD Negeri Seworan Kecamatan Wonosegoro, Kabupaten Boyolali pada muatan Bahasa Indonesia $60 \%$ pada siklus 1 dan 73,33\% pada siklus $280 \%$ pada siklus 2 .

\section{Saran}

Saran dalam penelitian ini: 1) Guru hendaknya menggunakan model pembelajaran yang melibatkan siswa dengan proyek dalam pembelajaran. 2) Guru hendaknya mengembangkan ketrampilan proses dalam pembelajaran agar dapat meningkatkan hasil belajar siswa.

\section{DAFTAR PUSTAKA}

Abdul Majid. 2006. Perencanaan Pembelajaran. Bandung: PT Remaja Rosda Karya.

Almes Gangga.2013. Penerapan Model Project Based Learning Dalam Meningkatkan Motivasi dan Hasil Belajar. Skripsi Universitas Negeri Padang Tidak diterbitkan.

Arikunto,S.,Suhardjono dan Supardi.(2008). Penelitian Tindakan Kelas. Jakarta: Bumi Aksara.

Bas, G dan Beyhan,o.(2010). Effect of multiple intelligences supported projectbased-learning on student'achivement levels and attitudes toward english lesson international electronic Journal of Elementry Education, Vol.2,Issue, July,2010. Diakses 12 September 2014 dari www.iejee.com/2 3 2010/365385.pdf/mirip.

Fogarty, Robin.2009. The Mindfull school how to intergrate the curticula. Ilinoses:Sky light Pub, Inc.

Hosnan. (2014). Pendekatan Saintifik dan Kontekstual Dalam Pembelajaran Abad 21. Bogor: Ghalia Indonesia.

Kemendikbud, (2014). Materi Pelatihan Implementasi Kurikulum 2013. Jakarta: Badan Pengembangan Sumber Daya Manusia Pendidikan dan Kebudayaan dan Penjaminan Mutu Pendidikan Kementerian Pendidikan dan Kebudayaan..

Nurhadi, Yasin, Burhan dan Senduk Agus Gerrad.2004.Pembelajaran Kontekstual dan Penerapanya dalam KBK.Malang: UM Press.

Peraturan Pemerintah(PP). No. 19 Tahun 2005 tentang Standar Nasional Pendidikan, Bab I, Pasal I.

Peraturan Pemerintah(PP) tentang Standar Nasional Pendidikan, Bab I, Pasal I.

Permendikbud Nomor 81 A Tahun 2013, Implementasi Kurikulum, Lampiran IV. Pedoman Umum Pembelajaran: Jakarta

Rais, Muh. 2010. Project Based Learning: Inovasi Pembelajaran yang Berorientasi Soft Skills. Makalah disajikan Sebagai makalah Pendamping dalam Seminar Nasional Pendamping dalam Seminar Nasional Pendidikan Teknologi dan Kejuruan Fakultas Teknik Universitas Negeri Surabaya 
Penerapan Pendekatan Saintifik Melalui Model Project Based Learning (Umi

Faizah)

tahun 2010. Surabaya: Unesa.

Rustaman, N.Y. 2005. Strategi Mengajar Biologi. Malang: Universitas Negeri Malang.

The Goerge Lucas Educatioanal Foundation.(2005). Intructional Module Project

Based Learning. Diakses 12 September 2014 dari http://www. Edutopia.org/modules/PBL/whatpnl.php.

Theresia Widayantini. 2014. Penerapan Model Project Based Learning dalam Materi Pola Bilangan Kelas VII. PPPPTK Matematika:Yogyakarta

Wahyudi \& Kriswandani. (2010). Pengembangan Pembelajaran Matematika SD. Salatiga: Fakultas Keguruan dan Ilmu Pendidikan - UKSW. 